\title{
Marital Satisfaction and Life Satisfaction: The Mediating Effect of Spirituality
}

\author{
Figen Kasapoğlu ${ }^{1}{ }^{10}$ \\ Inonu University
}

\author{
Ayşenur Yabanigül ${ }^{2}$ \\ Marmara University
}

\begin{abstract}
The present study aims to investigate the mediating role of spirituality in the relationship between couples' marital satisfaction and life satisfaction. The study was conducted following the relational design, one of the quantitative research methods. The study group included 586 married individuals residing in Istanbul, Turkey, of whom 525 were female and 61 were male. Three scales, the Married Life Scale the Life Satisfaction Scale, and the "Spiritual Orientation Scale, were used together with a demographic information form to collect data for the study. Moreover, descriptive statistics, correlation, and regression analyzes were conducted over the course of the study. The analysis findings demonstrated that marital satisfaction predicted life satisfaction and spirituality, that spirituality predicted life satisfaction, and that spirituality played a partial mediating role in the relation between marital satisfaction and life satisfaction. In other words, it was determined that marital satisfaction had both a direct and, via spirituality, a indirect impact on life satisfaction. The findings are discussed in light of the literature.
\end{abstract}

Keywords

Marriage $\bullet$ Marital Satisfaction $\bullet$ Spirituality $\bullet$ Life Satisfaction $\bullet$ Mediation

Evlilik Doyumu ve Yaşam Doyumu: Maneviyatın Aracılık Etkisi

Öz

$\mathrm{Bu}$ araştırmada, eşlerin evliliklerinden aldıkları doyum ile yaşam doyumları arasındaki ilişkide maneviyatın aracı rolünü incelemek amaçlanmıştır. Araştırmada nicel araştırma yöntemi olan ilişkisel desen benimsenmiştir. Araştırmanın çalışma grubunu İstanbul ilinde ikamet eden 525'i kadın ve 6l'i erkek olmak üzere 586 evli birey oluşturmaktadır. Araştırmada veri toplama aracı olarak, "Evlilik Yaşam Ölçeği", "Yaşam Doyumu Ölçeği", "Manevi Yönelim Ölçeği" ve demografik bilgi formu kullanılmıştır. Araştırmada, betimsel istatistikler, korelasyon ve regresyon analizleri yapılmışır. Yapılan analizlerin sonucuna göre, evlilik doyumunun yaşam doyumunu ve maneviyatı yordadığı; maneviyatın yaşam doyumunu yordadığı ve evlilik doyumu ile yaşam doyumu arasındaki ilişkide maneviyatın kısmi aracı rol üstlendiği saptanmıştır. Diğer bir deyişle, evlilik doyumunun hem doğrudan hem de maneviyat aracılığıyla yaşam doyumu üzerinde etkisi bulunmaktadır. Bulgular ilgili alan yazın çerçevesinde tartışılmıştır.

Anahtar Kelimeler

Evlilik • Evlilik Doyumu • Maneviyat • Yaşam Doyumu • Aracılık

1 Correspondence to: Figen Kasapoğlu (PhD Student), Institute of Educational Sciences, Guidance and Counseling, İnönü University, Malatya 44210 Turkey. Email: figenkasapoglu.721@gmail.com

2 PhD Student, Institute of Educational Sciences, Guidance and Counseling, Marmara University, Istanbul 34722 Turkey. Email: yabanigul.aysenur @gmail.com

Citation: Marital satisfaction and life satisfaction: The mediating effect of spirituality. Spiritual Psychology and Counseling, 3, 177-195. http://dx.doi.org/10.12738/spc.2018.3.2.0048 
Marriage life is considered a fundamental human relationship through which couples may satisfy their biological, psychological, and social needs (Özgüven, 2000). Marriage is also considered to be the primary means of building a family and raising future generations (Larson \& Holman, 1994). Certain studies have demonstrated that married individuals are, in general, not only happier but also physically and mentally healthier compared to their unmarried counterparts and especially compared to separated or divorced individuals (Diener, \& Diener-McGarvan, 2008; Diener, Suh, Lucas, \& Smith, 1999; Gove, Hughes, \& Style, 1983; Mookherjee, 1997; Myers, 2000; Rosen Grandon, Myers, \& Hattie, 2004; Salarifer, Musaviasl, Shukai, \& Devlethah, 2014). However, this happiness depends on the success and health of the marriage. Successful marriage entails adjustment, interaction, and sharing while also requiring partners to accept, maturely, the related obligations and responsibilities expected of them (Bilen, t.y.). In Turkey, studies on the factors leading to successful marriages demonstrated that, in general, such concepts as adjustment (e.g., Çelebi, 2016; Erbek, Beştepe, Akar, Eradamlar, \& Alpkan, 2005; Fidanoglu, 2006; Özbey, 2012; Soylu, \& Kağnıc1, 2015; Tutarel-Kışlak \& Göztepe, 2012), marriage quality (e.g., Gürel, 2016; Kurt, 2018), and marriage satisfaction (e.g., Cihan-Güngör, 2007; Çağ, 2016; Çakır, 2014; Hünler \& Gençöz, 2003; Yildiz \& Baytemir, 2016) were most effective.

Within the scope of the present study, marital satisfaction was the first concept to be scrutinized. Marital satisfaction is defined as an individual mental state that reflects the perceived benefits and costs of the marriage. The higher the cost, the lower the satisfaction perceived with the marriage and the partner, and similarly, the higher the perceived benefits, the higher the satisfaction obtained from the marriage and the partner (Stone \& Shackelford, 2007). Tezer (1986) described marital satisfaction as the subjective belief of the individual on the degree to which his or her needs are met in the marital relationship.

The studies on the belief systems and interaction patterns of happy couples in a longterm marriage reported that these marriages had distinctive features. For example, Lauer, Lauer, and Kerr (1990) investigated the factors that could lead to a stable and satisfactory marriage. The variables that couples identified as important for their marriage centered on certain goals and objectives, such as marrying a person whom they loved and with whom they enjoyed being together, who has a sense of humor, who is committed to his or her spouse and the marriage, and with whom one can share a life, friendship, and decision-making. Fenell (1993) investigated the characteristics of first marriages lasting over twenty years. In these long-term marriages, the 10 most important attributes that the spouses possessed were (i) a lifelong commitment to marriage, (ii) commitment to the spouse, (iii) strong moral values, (iv) respect for the spouse as one's best friend, (v) commitment to sexual loyalty, (vi) the desire to be a good parent, (vii) faith in God and spiritual commitment, (viii) the desire to satisfy and support one's spouse, (ix) the 
willingness to be a good spouse, and (x) to forgive the spouse. In another study, fifteen couples who were married for at least thirty years were asked to perceive the qualities with which they associated themselves during periods of intimacy and tension in their relationship. Key characteristics identified by the couples were autonomy, commitment, communication, religious orientation, perceived harmonious relationship, and balanced intimacy (Robinson \& Blanton, 1993). In a study, Craddock (1991) found that flexible and compatible couples experienced higher marital satisfaction when compared to couples whose marriages were chaotic and rigid. In the same study, it was also stated that there were positive correlations between marital satisfaction and similar religious orientations, similar personalities, conflict resolution skills, financial management agreement, leisure activities, children, family, and friends. Similarly, Schumm (1985) reported that religious orientation, communication quality, and the similarity of the time spent together were the most important determinants of marital satisfaction. Using path analysis, Rosen-Grandon et al. (2004) examined the variables related to marital satisfaction. The study results were consistent with 7 of the 10 most important attributes identified in the study by Fenell (1993). The present findings confirmed the relative significance of lifelong commitment, commitment to the spouse, strong moral values, the desire to be a good parent, faith in God, religious / spiritual commitment, and the desire for forgiveness and being forgiven. The attributes that were not strongly supported were the commitment to sexual loyalty, support of the spouse, and being a good friend for the spouse.

Another topic scrutinized in the present study was the concept of life satisfaction and its association with marital satisfaction. This concept, also called well-being, was defined as the state of being healthy, happy, and wealthy (Morris, 2001). According to moral philosophy, the most appropriate meaning of well-being is happiness toward one's entire life. Satisfaction, in this sense, reflects living a happy and virtuous life (Kwon, 2008). Life satisfaction is the cognitive aspect of subjective well-being, which implies an overall assessment of the individual's life (Diener, 1984, p. 544). In other words, life satisfaction is assessment of the attitude of the individual about satisfaction and dissatisfaction with her or his life (Heller, Watson, \& Ilies, 2006, p. 1422). Studies have demonstrated that married couples have higher levels of life satisfaction when compared to single or divorced individuals (Diener, Gohm, Suh, \& Oishi, 2000). Based on a study by Wilson (1967) on subjective well-being within the context of life satisfaction entitled Successful Happy Relationships, a happy individual is a young, healthy, well-educated, well-off, extravert, optimistic, carefree, pious, and married individual with high self-esteem, work ethic, and moderate approach in both genders. On the other hand, it was reported that relationship quality, rather than marriage alone, was the more important factor in predicting the life satisfaction (Carr, 2012; Ryan \& Deci, 2001; Salarifer et al., 2014). There is also evidence supporting the view that happier individuals build satisfactory marriages (Stutzer \& Frey, 2006). 
International and domestic studies have demonstrated a significant positive correlation between life satisfaction and marital satisfaction (Heller et al., 2006; Orbuch, House, Mero, \& Webster, 1996; Perrone-McGovern, Boo, \& Vannatter, 2012; Y1ldız \& Baytemir, 2016; Yıldız \& Büyükşahin, 2016). Similarly, significant positive correlations between subjective well-being and marital satisfaction, a concept that includes life satisfaction, were evidenced (Bayer, 2016; Canbulat \& Çankaya, 2014; Tülek, 2011). Furthermore, studies demonstrated that marital satisfaction was a significant predictor of life satisfaction (Celenk \& van de Vijver, 2013; Diener, 1984; Ng, Loy, Gudmunson \& Cheong, 2009; Perrone-McGovern et al., 2012; Y1ldız \& Baytemir, 2016). Studies on marriage demonstrated that various concepts, such as marriage quality, marital satisfaction, and marriage adjustment, were used as interchangeable concepts (Fincham \& Bradbury, 1987; Spanier \& Lewis, 1980). Thus, a positive and significant correlation was observed to exist between life satisfaction and marital quality (Çetinkaya \& Gençdoğan, 2014) and marital adjustment (Arshad, Mohsin, \& Mahmood, 2014; Çelik \& Tümkaya, 2012; Ümmet, 2017).

Another topic scrutinized in the present study was the correlation between spirituality and marital satisfaction. Spirituality is reported to be a strong contributing factor to marital life (Fenell, 1993; Greeley, 1991; Hunler \& Gencoz, 2005; Rosen-Grandon et al., 2004). On the other hand, marriage provides a significant space for individuals to reach spiritual culmination (Salarifer et al., 2014). As a concept, spirituality indicates the quality of human existence that includes the belief in a transcendent force or entity and a sense of deep commitment to the universe and to integrity (Myers, Sweeney, \& Witmer, 2000, p. 252). Spirituality reflects the connection of an individual with his own self, others, nature, and transcendence. The connection of the individual with the self is expressed with the concepts of uniqueness, inner harmony / inner peace, consciousness, self-knowledge, and searching for the meaning of life. The connection with others and with nature is about compassion, kindness, gratitude, and admiration. The connection with transcendence includes transcendental reality, a higher power, or a connection with God or an entity beyond the human level (Meezenbroek et al., 2012; Sweeney \& Witmer, 1991; Witmer \& Sweeney, 1992). Simply, spirituality is a concept beyond the physical, psychological, or social dimensions of life. The relational and transcendental presence of spirituality is labeled as divine, a higher power, divine entity, ultimate reality, God or god-being (Sawatzky, Ratner, \& Chiu, 2014). For example, prayer and worship are used as a means and a resource to solve complex and troublesome problems. Thus, spirituality does not only exist as a belief in human life, but also possesses functional spiritual qualities (Kwon, 2008).

For several individuals in Turkey, spirituality and religion constitute an important aspect of their lives. In a study on the religious life in Turkey conducted by The Directorate of Religious Affairs (2014), it was reported that 99\% of married 
individuals believed that there is a God and is One and never doubted that fact. Based on the correlation between spirituality and marriage life, this fact makes it worthwhile to investigate the mediating role of spirituality in the correlation between marital satisfaction and life satisfaction.

A literature review demonstrates a positive correlation between spirituality and marital satisfaction (David \& Stafford, 2015; Ellison, Burdette, \& Wilcox, 2010; Fincham, Ajayi, \& Beach, 2011; Giblin, 1997; Greeley, 1991; Hunler \& Gencoz, 2005; Kallampally, Oakes, Lyons, Greer, \& Gillespie, 2008; Mahoney, 2010; PerroneMcGovern et al., 2012; Roth, 1988; Strycharz, 2004). It was reported that the dimensions of spirituality influential on marriage life were: problem-solving, the establishment of adequate communication style, sexuality, and decision-making (Giblin, 1997; Hünler \& Gençöz, 2003). Although there are differences between spirituality and religion, since there are common attributes of both structures (Turner, Lukoff, Barnhouse, \& $\mathrm{Lu}, 1995)$, the studies on religiosity and marital satisfaction were also scrutinized. Similarly, positive correlations between religiosity and marital satisfaction were determined (Anthony, 1993; Balci Arvas, 2017; Brimhall \& Butler, 2007; Dudley \& Kosinski, 1990; Fincham, Stanley \& Beach, 2007; Hunt \& King, 1978; Sullivan, 2001; Wolfinger \& Wilcox, 2008). It was also reported that religion facilitated coping with marital problems and played a protective role against divorce (Balc1 Arvas, 2017) and that there was a negative correlation between domestic violence and attendance to religious services (Ellison, Bartkowski, \& Anderson, 1999).

Another correlation examined in the present study was the association between spirituality and life satisfaction. Studies in the literature demonstrated a positive correlation between spirituality and life satisfaction (Genia \& Cooke, 1998; Joshanloo \& Daemi, 2014; Perrone-McGovern et al., 2012; Wills, 2009; Zullig, Ward, \& Horn, 2006). Similarly, there was a significant correlation between spirituality and subjective well-being (Öztürk \& Siviş Çetinkaya, 2015) and happiness (Aydoğan, Özbay and Büyüköztürk, 2017). In general, individuals who characterized themselves as spiritual reported more positive emotions and life satisfaction when compared to nonspiritual individuals (Cohen, 2002; Van Dierendonck \& Mohan, 2006). Lipsey and Wilson (2001) utilized the meta-analysis method to explore the correlation between spirituality and life satisfaction. The findings of the meta-analysis demonstrated that the conceptualization of spirituality led to elements supported as a separate concept related to quality of life. It was observed that the mean effect size remained consistent across differences in the sample based on gender, age, and ethnicity. In a similar metaanalysis, the random effect model of the bivariate correlation between spirituality and quality of life led to a moderate effect size $(r=0.34,95 \%$ CI: $0.28-0.40)$. Thus, spirituality was described as a unique concept in its correlation with the quality of life (Sawatzky et al., 2014). 
The criteria for life satisfaction and spirituality vary between cultures. Therefore, assessments on such concepts as subjective well-being and life satisfaction and spirituality should be conducted based on each individual culture's understanding. There is ample evidence that religion and spirituality are positively associated with psychological health in western cultures (Wills, 2009). The process of achieving spiritual well-being varies among different cultures and even among individuals in these cultures. Furthermore, spiritual satisfaction is both an instrument and an extension of physical and psychological well-being and satisfaction. For example, during meditation, an individual can attain an increased level of awareness and achieve personal happiness and life satisfaction. This view is more dominant in Western culture, which is focused on individual development. On the other hand, more collective Eastern cultures utilize the meditation and the meditative role of spirituality to develop ties with others, advocating an approach focused on others. In other words, instead of individual well-being, it is more important to be well with someone else and do something good for someone else for self-wellbeing (Kwon, 2008). Given the role of spirituality in general, it is observed that the concept of spiritual is assessed from the health perspective similar to the concepts of wellbeing and satisfaction. Spiritual health represents the functional dimensions rather than theological and religious beliefs. In other words, spirituality is not a matter of finding a religion for oneself, but a tool that helps individuals to receive that which they need or as much of what they need to improve their life satisfaction (Sawatzky et al., 2014). The function of spirituality here is the facility it provides to observe different religious practices among different individuals. It can also be used to find a solution to rebalance an imbalanced life style by an individual.

Within the scope of the present study, the correlations between marital satisfaction, life satisfaction, and spirituality were investigated. A similar study examining these three variables was conducted by Perrone et al. (2006). In their study, they investigated the correlation between life satisfaction and a combination of spirituality, professional roles, and marital roles among gifted adults. The results demonstrated that spiritual well-being and marital satisfaction were significant contributors to life satisfaction. In response to open-ended questions, participants added several aspects that spirituality affected their work, marriages, parenting, and life satisfaction.

Based on the above information, an analysis of the international and domestic studies demonstrated that the correlation between the concepts is still vague and needs to be enriched despite the empirical evidence for the associations among marital satisfaction, spirituality, and life satisfaction. It is known that marital life is significant in Turkey. However, according to data compiled by the Turkish Statistics Institute and from the media, the number of new marriages decreased while the number of divorces increased over the last 10 years (2008-2017) (https://www.cnnturk.com/ 
turkiye/). Thus, the significance of studies on marital relationships and satisfaction are discernible. It was suggested that marriage problems could lead to problems in other areas of the individual's life. On the other hand, it was assumed that marital satisfaction affects partners' quality of life and satisfaction directly and through certain variables indirectly. There are no previous studies on the correlations between marital satisfaction, spirituality, and life satisfaction variables in Turkey. Therefore, the present study aimed to contribute to the literature in this field. Correlated to marital satisfaction, spirituality also plays an important role in life satisfaction. Since spirituality is closely related to both marital and life satisfaction, it is anticipated that it play a mediating role between these two variables. Thus, individuals' marital satisfaction and their positive assessments on spirituality could be correlated with their greater satisfaction in life. In this perspective, the aim of the present study was to analyze the correlation between marital and life satisfaction and the mediating role of spirituality in this correlation for married individuals. The study hypotheses were determined as follows:

H1: There is a significant and positive correlation between marital and life satisfaction.

$\mathrm{H} 2$ : There is a significant and positive correlation between marital satisfaction and spirituality.

H3: There is a significant and positive correlation between spirituality and life satisfaction.

H4: Spirituality plays a mediating role in the correlation between marital satisfaction and life satisfaction.

\section{Method}

Relational design, a quantitative research method aiming to investigate the correlation between two or more variables, was used in the present study (Heppner, Wampold, \& Kivlighan, 2013). Based on the study objective, marital satisfaction was selected as the predictor variable, spirituality as the mediator variable, and life satisfaction as the predicted variable. To determine the mediating effect, the method described by Baron and Kenny (1986) was utilized in the regression analysis.

\section{The Study Group}

The study population included married individuals residing in the province of Istanbul, Turkey. Since the criterion for participation was being married and due to the difficulty of reaching volunteering married individuals, the study was conducted with a convenience sample. The study sample included 586 married individuals, out 
of whom $525(89.6 \%)$ were female and $61(10.4 \%)$ were male. Couples who had been married for at least one year were selected as participants in the study. Of the married individuals participating in the study, $41 \%$ were $31-40$ years old whereas $28 \%$ were 20 30 years old. The participants had been married for 1 to 40 years at the time of the study. Of these, $30 \%$ had been married for $1-5$ years and $20 \%$ for $31-40$ years. Of the total 586 participants, $127(21.7 \%)$ were employed in the public sector and $459(78.3 \%)$ had other professions. Furthermore, 33 (5.6\%) participants were primary school, $15(2.6 \%)$ were middle school, and 106 (18.1\%) were high school graduates whereas 284 (48.5\%) had received undergraduate and $148(25.3 \%)$ had received graduate degrees.

\section{Data Collection Instruments}

Married Life Scale (MLS). The scale was developed by Tezer (1986) to measure the general satisfaction levels of partners in marriage. It is a five-point Likert-type scale that includes ten questions whose test-retest reliability was $r=.85$ and whose internal consistency was .88 for males and .91 for females. Significant differences were found between the mean scores of married and divorced individuals in the MLS ( $t=$ $6.23, \mathrm{p}<0.01$ ), and this finding was considered as evidence for the validity of the scale when compared to the external scale. Regarding reliability, Cronbach's alpha internal consistency coefficient was calculated as .89 .5 for the scale in the present study.

Life Satisfaction Scale (LSS). Adapted to Turkish by Köker (1991), this scale was developed by Diener et al. (1985) to determine individuals' life satisfaction levels of individuals. The scale includes 5 items, each item of which has 7 options ranging from "completely disagree" to "completely agree." Regarding reliability, Cronbach's alpha internal consistency coefficient was calculated as. 83 for the scale in the present study.

Spiritual Orientation Scale. Developed by Kasapoğlu (2015), the Spiritual Orientation Scale was used to analyze participants' spiritual orientations in the study. The 7-point Likert type scale includes 16 items. A high scale score indicates that the spiritual orientation of the individual is high. Explanatory and confirmatory factor analysis techniques were utilized for the construct validity studies conducted on the scale. As a result of the explanatory factor analysis, a one-dimensional structure was obtained. Cronbach's lphas reliability coefficient was calculated to evaluate the reliability of the scale, and it was found that the test retest reliability coefficient was .84 . In the present study, Cronbach's alpha coefficient was calculated as .90 for the scale.

Demographic information form. Developed by the authors, this form was used to determine participant demographics, including gender, age, duration of marriage, education level, and profession. 


\section{Procedure}

The data for the study were collected from volunteering married individuals via Google Drive in between November and December of 2017 from 663 participants. After analysis assumptions were tested, 19 participants were excluded from the analysis due to missing and imprecise responses. Mahalanobis distances were determined during the data analysis and accordingly, the accepted critical value for the two independent variables was found to be $9.21, \mathrm{p}=.01$ (Can, 2014, p. 283). Thus, 42 pieces of data with a Mahalanobis value of over 9.21 were excluded from the analysis and the remaining 586 were analyzed. The data analysis was conducted following descriptive statistics, correlation, multiple and linear regression analysis techniques. The multivariate and linear regression analyses were found to satisfy normality and linearity assumptions. VIF and Tolerance values were within acceptable limits. In order to determine the mediation effect in the regression analysis, the method described by Baron and Kenny (1986) was adopted. The significance of the mediation effect was determined through the Sobel test. Analyzes were conducted using SPSS 24.0 software.

\section{Results}

In this section, marital satisfaction is taken as the predictor variable, life satisfaction as the predicted variable, and spirituality as the mediator variable. To determine the mediating effect, we conducted a regression analysis following the conditions proposed by Baron and Kenny (1986): (i) the correlation between predictor and predicted variables should be significant, (ii) the correlation between mediator variable and predictor variable should be significant, (iii) there should be a significant correlation between the mediator and predictor variables while both the mediator variable and predictor variable predicted the predicted variable, (iv) when the mediator variable and the predictor variable are tested in the regression analysis simultaneously, the significant correlation between the predictor and the predicted variable should no longer be significant (full mediation) or the previous level of significance should decrease (partial mediation) (p.1176). These conditions were tested with three regression equations. Whether the first condition was met was determined through a regression equation where marital satisfaction was the predictor and life satisfaction the predicted variable. However, when testing this equation, if there is another variable known or estimated to interfere with the correlation, it is necessary to control the effect of this variable (Aracilık, T.Y., para. 5). Thus, the gender variable was checked and was determined to have no significant impact. The second condition was also tested with a regression equation where marital satisfaction was again a predictor variable but with spirituality being the predicted variable. The third and fourth conditions were confirmed by testing a single regression equation. In this equation, the effects of both marital satisfaction and spirituality as independent variables on life satisfaction were calculated. The abovementioned correlation and regression analyzes are presented below. 


\section{Correlation Analysis}

The means, standard deviations, and correlations of the variables used in the study (i.e., marital satisfaction, spirituality, and life satisfaction) are presented in Table 1.

Table 1

Correlations Between Means/Standard Deviations and Variables

\begin{tabular}{cccc}
\hline Variable & Spirituality & Life Satisfaction & Marital Satisfaction \\
\hline Life Satisfaction & $.24^{*}$ & - & - \\
Marital Satisfaction & $.19^{*}$ & $.67^{*}$ & - \\
Mean $(S D)$ & $105.37(6.99)$ & $24.76(5.84)$ & $37.45(7.62)$ \\
\hline
\end{tabular}

$*_{p}<.001 . S D:$ Standard Deviation.

Table 1 demonstrates that there are positive and significant correlations between marital satisfaction and spirituality $(\mathrm{r}=.19, \mathrm{p}<.001)$, between life satisfaction and spirituality $(\mathrm{r}=.24, \mathrm{p}<.001)$, and between marital satisfaction and life satisfaction $(\mathrm{r}=.67, \mathrm{p}<.001)$.

\section{Regression Analyses}

\section{Prediction of life satisfaction by marital satisfaction.}

The results of the regression analysis conducted to determine of life satisfaction by marital satisfaction are presented in Table 2.

Table 2

Regression Analysis on the Prediction of Life Satisfaction by Marital Satisfaction

\begin{tabular}{lcccc}
\hline Predictor Variable & B & Standard Error & $\beta$ & $t$ \\
\hline Marital Satisfaction & .51 & .02 & .67 & $21.78^{* * *}$ \\
\hline$\left(R=.67, R^{2}=.45, F=474.5, p<.001\right)$ & & & & \\
\hline$* * * p<.001$. Predicted Variable: Life Satisfaction. & & &
\end{tabular}

Table 2 illustrates that marital satisfaction predicted life satisfaction at a significant level $\left(\mathrm{F}_{1,584}=474.5, \mathrm{p}<.001\right)$ and explained $45 \%$ of the total variance.

\section{Prediction of spirituality by marital satisfaction.}

The results of the regression analysis conducted to determine the prediction of spirituality by marital satisfaction are presented in Table 3.

Table 3

Regression Analysis on the Prediction of Spirituality by Marital Satisfaction

\begin{tabular}{lcccc}
\hline Predictor Variable & $\mathrm{B}$ & Standard Error & $\beta$ & $t$ \\
\hline Marital Satisfaction & .17 & .04 & .19 & $4.6^{* * *}$ \\
\hline$\left(R=.19, R^{2}=.04, F=21.125, p<.001\right)$ & & & & \\
\hline$* * * p<.001$. Predicted Variable: Spirituality. & & &
\end{tabular}

Table 3 shows that marital satisfaction predicted spirituality at a significant level $\left(\mathrm{F}_{1,584}=21.13, p<.001\right)$ and explained $4 \%$ of the total variance. 


\section{The mediating role of spirituality in the relationship between marital satisfaction and life satisfaction.}

The results of the regression analysis conducted to determine the mediating effect of spirituality in the relation between marital satisfaction and life satisfaction are presented in Table 4.

\section{Table 4}

The Results of the Regression Analysis on the Mediating effect of Spirituality in the Relationship between Marital Satisfaction and Life Satisfaction

\begin{tabular}{llccc}
\hline Predictor Variable & B & Standard Error & $\beta$ & $t$ \\
\hline Marital Satisfaction & .50 & .02 & .65 & $20.8^{* * *}$ \\
Spirituality & .10 & .03 & .12 & $20.9^{* * *}$ \\
\hline
\end{tabular}

$\left(R=.68, R^{2}=.46, F=249.6, p<.001\right)$

$* * * p<.001$. Predicted Variable: Life Satisfaction.

As seen in Table 4, predictor and mediating variables were simultaneously tested in the analysis. Thus, it was observed that spirituality (mediating variable) significantly and positively predicted life satisfaction $(\beta=.12, \mathrm{p}<.001)$. On the other hand, the marital satisfaction's effect on life satisfaction decreased from $\beta=.67$ to $\beta=.65$. The decrease in marital satisfaction's impact observed after spirituality was included in the model combined with the fact that its impact was still significant demonstrates that spirituality is a partial mediator. In other words, marital satisfaction had both a direct and indirect effect via spirituality on life satisfaction. A Sobel test was conducted to determine the significance of the partial mediation $(\mathrm{z}=4.58656317, \mathrm{p}<.0001)$. The findings indicate that in addition to its direct effect, marital satisfaction indirectly affects life satisfaction through spirituality. A high level of marital satisfaction should improve life satisfaction both directly and indirectly through spirituality. The standardized beta values of the relevant variables are presented in Figure 1.

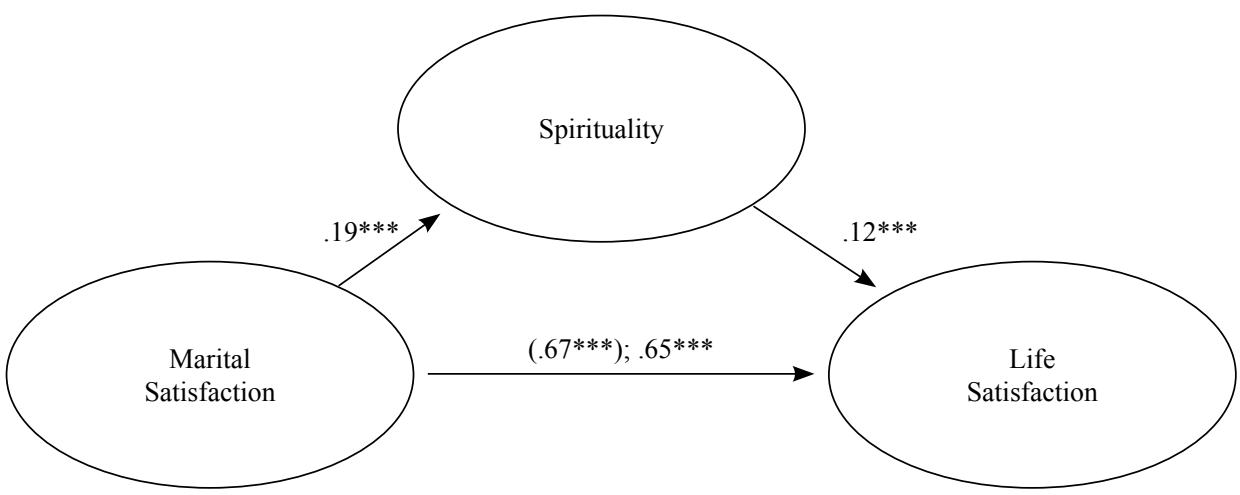

Figure 1. The Mediating Effect of Spirituality on the Impact of Marital Satisfaction on Life Satisfaction and Standardized Beta Coefficients. $(* * * p<.001)$. 


\section{Discussion}

In the present study, the mediating effect of spirituality on the correlation between marital satisfaction and life satisfaction was examined. The findings demonstrated that the study hypothesis was confirmed.

The first study hypothesis stating that there is a significant correlation between marital satisfaction and life satisfaction was confirmed. As individuals' marital satisfaction levels increased, so too did their levels of life satisfaction. This finding is consistent with those of previous studies (Celenk \& van de Vijver, 2013; Diener, 1984; Heller et al., 2006; Ng et al., 2009; Orbuch et al., 1996; Perrone-McGovern et al., 2012; Yildiz \& Baytemir, 2016, Yildiz \& Büyükşahin, 2016). Similarly, positive and significant correlations were found between life satisfaction and quality of marriage (Çetinkaya \& Gençdoğan, 2014) and marital adjustment (Arshad et al., 2014; Çelik \& Tümkaya, 2012; Ümmet, 2017), and between marital satisfaction and subjective well-being (Bayer, 2016; Canbulat \& Çankaya, 2014; Tülek, 2011). Although marriage is generally a means leading individuals to mutual happiness, marriage quality, as opposed to marriage alone, was a more significant factor (Ryan \& Deci, 2001; Seligman, 2007). It could be suggested that higher perceived benefits from marriage compared to costs (Stone \& Shackelford, 2007) would increase life satisfaction. Furthermore, marital satisfaction could increase the individuals' life satisfaction levels by improving their self-respect (Yıldiz \& Baytemir, 2016). Similarly, being satisfied with one's marriage could improve overall life satisfaction by contributing to the individuals' psychological health (Ümmet, 2017). In brief, when individuals are happy with and attain harmony from their marriage, it follows that they should be satisfied with life and have high well-being.

The second study hypothesis stating that there is a significant correlation between marital satisfaction and spirituality was confirmed. Based on the findings, marital satisfaction predicted individuals' spirituality. The positive correlation between marital satisfaction and spirituality was consistent with other studies in the literature (David \& Stafford, 2015; Ellison et al., 2010; Fincham et al., 2011; Giblin, 1997; Greeley, 1991; Hunler \& Gencoz, 2005; Kallampally et al , 2008; Mahoney, 2010; Perrone-McGovern et al., 2012; Roth, 1988). Based on this finding, as individuals' marital satisfaction increased, so too did their spirituality. Similar to spiritual beliefs being described as a strong factor contributing to marital life in previous studies (Greeley, 1991; Hunler \& Gencoz, 2005), the present study's findings likewise reflect the notion that marital satisfaction has a positive effect on spirituality. In fact, marriage introduces a significant space for individuals' spiritual culmination (Salarifer et al., 2014). Thus, it can be suggested that individuals satisfied with their marriage are more spiritual in regard to the meaning of life, inner harmony, inner peace, inner integrity, experiencing transcendental experiences, and being connected with others. 
The third study hypothesis stating that there is a significant correlation between spirituality and life satisfaction was also confirmed. The findings of several studies in the literature are with consistent our findings (Cohen, 2002; Genia \& Cooke, 1998; Joshanloo \& Daemi, 2014; Öztürk \& Sivis-Cetinkaya, 2015; Perrone-McGovern et al., 2012; Sawatzky et al., 2014; van Dierendonck \& Mohan 2006; Wills, 2009; Zullig et al., 2006). Several possible explanations could be provided for this positive correlation. Spirituality is an element that helps individuals to obtain what they need or the amount that they need to improve their satisfaction with life. Spirituality can be a functional and powerful factor in helping one rebalance an unbalanced life because it has the power to lead individuals to develop a deep feeling of meaning and purpose in the existential anxiety the experience and also to provide answers for basic existential questions (Greeley, 1991). Spirituality might also contribute to individuals' well-being by increasing their self-respect (Joshanloo and Daemi, 2014).

The final study hypothesis was also confirmed. It was observed in mediation analysis that when the mediating variable spirituality was involved, the direct correlation between the predictor variable (i.e., marital satisfaction) and the predicted variable (i.e., life satisfaction) decreased while the correlation remained significant. Thus, it could be suggested that marital satisfaction both directly and indirectly affects life satisfaction via spirituality. Spiritual beliefs and religious orientation are among the dynamics of long-term happy marriages (Craddock, 1991; Fenell, 1993; Robinson and Blanton, 1993; Rosen-Grandon et al., 2004; Schumm, 1985). It could therefore be suggested that spiritual beliefs help married individuals create an emotional bond that increases marital satisfaction. Married individuals are faced with various stressful events throughout their lives and need to adapt to these conditions. As spirituality allows the individuals to acquire a sense of hope, power, and peace (Perrone-McGovern et al., 2012), the elements of spirituality, compassion, compassion, and gratitude (Sweeney \& Witmer, 1991; Witmer \& Sweeney, 1992), it could be a strong factor in coping with the marital stress and problems and an important structure facilitating adaptation to the conditions of marriage. Spirituality helps individuals learn to accept self-identity, to forgive others and oneself, to accept one's own deficiencies and personal responsibilities, to give up on anger, to cope with guilt, and to alter self-destructive thinking, emotions, and role-patterns (Burke, Chauvin, \& Miranti, 2005). Thus, spirituality could allow individuals to recognize themselves, develop positive emotions, and be satisfied with their lives.

Statistics demonstrated that the number of couples having gotten married has decreased, while the number of divorces has increased over the last decade (https:// www.cnnturk.com/turkiye/). This could indicate that the desired marital satisfaction was not able to be easily achieved and that the institution of marriage is under serious strain. The present study findings demonstrated that spirituality could significantly 
contribute to the correlation between marital satisfaction and general life satisfaction, and this finding has important implications for psychological counseling as a whole.

The findings of the present study are limited to the study sample group. The fact that the majority of participants were women could be considered another limitation of the study. Participation in the study being of a voluntary nature is thought to have caused such a gender distribution. Furthermore, the findings themselves were limited by the data obtained and the measurement instruments used to collect these data were limited since they were based on self-assessment.

Certain recommendations could be made for researchers and practitioners based on the findings and limitations in the present study: (i) Future studies could examine additional mediating variables that might be effective on the correlation between marital satisfaction and spirituality, as well as variables that could play a mediating role between spirituality and life satisfaction. (ii) Since spirituality plays a mediating role between marital satisfaction and life satisfaction, mediation models examining the covariance of those variables related to spirituality could be tested. (iii) The marital and life satisfaction levels of married individuals could be improved by field specialists via psychological counseling with married couples in order to improve their marital satisfaction and spirituality.

\section{References}

Anthony, M. (1993). The relationship between marital satisfaction and religious maturity. Religious Education, 88, 97-108.

Aracılık. (t.y.). Yapısal eşitlik modellemesi. Retrieved from http://www.yapisalesitlik.com/yem.php?gln

Arshad, M., Mohsin, M. N., \& Mahmood, K. (2014). Marital adjustment and life satisfaction among early and late marriages. Journal of Education and Practice, 5(17), 83-90.

Aydoğan, D., Özbay, Y., \& Büyüköztürk, Ş. (2017). Özgünlük Ölçeği'nin uyarlanması ve özgünlük ile mutluluk arasındaki ilişkide maneviyatın aracı rolü. The Journal of Happiness ve WellBeing, 5(1), 38-59.

Balcı Arvas, F. (2017). Dindarlığın evlilik doyumu üzerindeki etkileri ve değerlerin, dindarlık ve evlilik doyumu ilişkisi üzerindeki arabulucu rolü (Doktora tezi, Uludağ Üniversitesi Sosyal Bilimler Enstitüsü, Bursa). Retrieved from https://tez.yok.gov.tr/UlusalTezMerkezi/

Baron, R. M., \& Kenny, D. A. (1986). The Moderator-mediator variable distinction in social psychological research: Conceptual, strategic, and statistical considerations. Journal of Personality and Social Psychology, 51(6), 1173-1182.

Bayer, Ö. (2016). Evli bireylerde evlilik doyumu ve çok boyutlu algılanan sosyal desteğin öznel iyi oluş üzerindeki yordayıcı rolünün incelenmesi. International Conference of Strategic Research in Social Science and Education, 14(16), 116-133.

Bilen, M. (t.y.). Sağlıklı insan ilişkileri. Ankara: Armoni LTD. ŞTİ. 
Brimhall, A. S., \& Butler, M. H. (2007). Intrinsic vs. extrinsic religious motivation and the marital relationship. The American Journal of Family Therapy, 35(3), 235-249. http://dx.doi. org/10.1080/01926180600814684

Burke, M. T., Chauvin, J. C., \& Miranti, J. G. (2005). Religious and spiritual issues in counseling: Applications across diverse populations. New York: Brunner-Routledge.

Can, A. (2014). SPSS ile bilimsel araştırma sürecinde nicel veri analizi. Ankara: Pegem Akademi.

Canbulat, N., \& Çankaya, Z. C. (2014). Evli bireylerin öznel iyi olma düzeylerinin yordanması. Ege Eğitim Dergisi, 15(2), 556-576.

Cihan Güngör, H. (2007). Evlilik doyumunu açıklamaya yönelik bir model geliştirme (Doktora tezi, Gazi Üniversitesi Eğitim Bilimler Enstitüsü, Ankara). Retrieved from https://tez.yok.gov. tr/UlusalTezMerkezi/

Celenk, O., \& van de Vijver, F. J. (2013). What makes couples happy? Marital and life satisfaction among ethnic groups in the Netherlands. Journal of Cross-Cultural Psychology, 44(8), 12751293. http://dx.doi.org/10.1177/0022022113486003

Cohen, A. B. (2002). The importance of spirituality in well-being for Jews and Christians. Journal of Happiness Studies, 3, 287-310.

Craddock, A. E. (1991). Relationships between attitudinal similarity, couple structure, and couple satisfaction in married and de facto couples. Australian Journal of Psychology, 43, 11-16.

Çağ, P. (2016). Evlilik doyumu: Bir model testi (Doktora tezi, Hacettepe Üniversitesi Eğitim Bilimler Enstitüsü, Ankara). Retrieved from https://tez.yok.gov.tr/UlusalTezMerkezi/

Çakır, O. (2014).Evlilik doyumunu açıklamaya yönelik bir model: Uyumsuz şemalar, bağlanma stilleri ve duygusal düzenleme (Doktora tezi, Hacettepe Üniversitesi Eğitim Bilimler Enstitüsü, Ankara). Retrieved from https://tez.yok.gov.tr/UlusalTezMerkezi/

Çelik, M. \& Tümkaya, S. (2012). Öğretim elemanlarının evlilik uyumu ve yaşam doyumlarının iş değişkenleri ile ilişkisi. Ahi Evran Üniversitesi Kırşehir Eğitim Fakültesi Dergisi, 13(1), 223-238.

Çetinkaya, S. K., \& Gençdoğan, B. (2014). The relationship between marital quality, attitudes towards gender roles and life satisfaction among the married individuals. Psychology, Society, \& Education, 6(2), 94- 112.

David, P. \& Stafford, L. (2015). A relational approach to religion and spirituality in marriage: The role of couples' religious communication in marital satisfaction. Journal of Family Issues, 36(2), 232-249. http://dx.doi.org/10.1177/0192513X13485922

Diener, E. (1984). Subjective wellbeing. Psychological Bulletin, 95(3), 542-575.

Diener, E., Suh, E., Lucas, R. E., \& Smith, H. L. (1999). Subjective well-being: Three decades of progress, Psychological Bulletin, 125, 276-302.

Diener, E., Gohm, C., Suh, E., \& Oishi, S. (2000). Similarity of the relations between marital status and subjective wellbeing across cultures. Journal of Cross-Cultural Psychology, 31, 419-436. http://dx.doi.org/10.1177/0022022100031004001

Diener, M. L., \& Diener McGavran, M. B. (2008). What makes people happy? A developmental approach to the literature on family relationships and well-being. In M. Eid \&R. Larsen (Ed.).The science of subjective well-being (ss. 347-375). New York: Guilford Press.

Diyanet İşleri Başkanlığı. (2014). Türkiye'de dini hayat. Retrieved from http://www2.diyanet.gov. tr/StratejiGelistirme/ 
Dudley, M. \& Kosinski, F. (1990). Religiosity and marital satisfaction: a research note. Review of Religious Research, 32, 78-86.

Ellison, C. G., Bartkowski, J. P., \& Anderson, K. L. (1999). Are there religious variations in domestic violence?Journal of Family Issues, 20(1), 87-113. http://dx.doi.org/10.1177/019251399020001005

Ellison, C. G., Burdette, A. M.,\& Wilcox, W. B. (2010). The couple that prays together: Race and ethnicity, religion, and relationship quality among working-age adults. Journal of Marriage and Family, 72, 963-975. http://dx.doi:10.1111/j.1741-3737.2010.00742.x

Erbek, E., Beştepe, E., Akar, H., Eradamlar, N.\&Alpkan, R. L. (2005). Evlilik uyumu. Düşünen Adam, 18(1), 39-47.

Fenell, D. L. (1993). Characteristics of long term marriages. Journal of Mental Health Counseling, $15,446-460$.

Fidanoğlu, O. (2006). Evlilik uyumu, mizah tarzı ve kaygı düzeyi arasındaki ilişki (Yüksek lisans tezi, Marmara Üniversitesi, İstanbul). Retrieved from https:/tez.yok.gov.tr/UlusalTezMerkezi/

Fincham, F. D., \& Bradbury, T. N. (1987). The assessment of marital quality: A reevaluation. Journal of Marriage and the Family, 49(4), 797-809. doi: 10.2307/351973

Fincham, F. D., Ajayi, C., \& Beach, S. R. (2011). Spirituality and marital satisfaction in African American couples. Psychology of Religion and Spirituality, 3(4), 259-268. https://doi. org/10.1037/a0023909

Genia, V., \& Cooke, B. A. (1998). Women at midlife: Spiritual maturity and life satisfaction. Journal of Religion and Health, 37(2), 115-124.

Gove, W. R., Hughes, M., \& Style, C. B. (1983). Does marriage have positive effects on the wellbeing of the individual? Journal of Helth and Social Behavior, 24, 122-131.

Greeley, A. M. (1991). Faithful attraction: Discovering intimacy, love and fidelity in American marriage. New York, NY: Tome Doherty Associates.

Heller, D., Watson, D., \&Illies, R. (2006). The dynamic process of life satisfaction. Journal of Personality, 74(5), 1421-1450. http://dx.doi.org/10.1111/j.1467-6494.2006.00415.x

Heppner, P. P., Wampold, B. E., \& Kivlighan, D. M., Jr. (2013). Psikolojik danışmada araştırma yöntemleri (D. M. Siyez, Çev.) Ankara: Mentis Yayıncılık.

Hunler, O. S., \& Gencoz, T. (2005). The effects of religiousness on marital satisfaction: Testingthe mediator role of marital problem solving between religiousness and marital satisfaction relationship. Contemporary Family Therapy: An International Journal, 27,123-126.

Hünler, O. S., \& Gençöz, T. (2003). Boyun eğici davranışlar ve evlilik doyumu ilişkisi: Algılanan evlilik problemleri çözümünün rolü. Türk Psikoloji Dergisi, 18(51), 99-108.

Hunt, R. \& King, M. (1978). Religiosity and marriage.Journal for the Scientific Study of Religion, 17, 399-406.

Joshanloo, M., \& Daemi, F. (2014). Self esteem mediates the relationship between spirituality and subjective wellbeing in Iran. International Journal of Psychology. http://dx.doi.org/10.1002/ ijop.12061

Kallampally, G. A., Oakes, K. E., Lyons, H. Z., Greer, J. M., \& Gillespie, C. K. (2008). Gender, psychological resilience, acculturation and spirituality as predictors of Asian Indian American marital satisfaction. Journal of Spirituality in Mental Health, 10(1), 35-52. http://dx.doi:10.1300/ J515v10n01_04 
Kasapoğlu, F. (2015). Manevi Yönelim Ölçeği’nin geliştirilmesi: Geçerlik ve güvenirlik çalışması. İönü Üniversitesi,16(3), 51-68. http://dx.doi.org/10.17679/iuefd.16360640

Köker, S. (1991). Normal ve sorunlu ergenlerin yaşam doyumu düzeylerinin karşılaştırılması (Yüksek lisans tezi, Ankara Üniversitesi Sosyal Bilimler Enstitüsü, Ankara). Retrieved from https://tez.yok.gov.tr/UlusalTezMerkezi/

Kurt, İ. E. (2018). Ebeveynlik stresi ve evlilik kalitesi arasındaki ilişside stresle çift olarak baş etmenin aracı rolünün incelenmesi (Doktora tezi, Çukurova Üniversitesi Sosyal Bilimler Enstitüsü, Adana). Retrieved from https://tez.yok.gov.tr/UlusalTezMerkezi/

Kwon, S.Y. (2008). Wellbeing and spirituality from a Korean perspective: based on the study of culture and subjective wellbeing. Pastoral Psychology, 56, 573-584.

Larson, J. H., \& Holman, T. B. (1994). Predictors of marital quality and stability. Family Relations, 43, 228 -237. https://doi.org/10.2307/585327

Lauer, R. H., Lauer, J. C., \& Kerr, S. T. (1990). The long term marriage: Perceptions of stabilityand satisfaction. International Journal of Aging and Human Development,31, 189-195. https://doi. org/10.2190/H4X7-9DVX-W2N1-D3BF

Lipsey, M. W., \&Wilson, D. B. (2001). Applied social research methods series; Vol. 49. Practical meta-analysis. Thousand Oaks, CA, US: Sage Publications, Inc.

Mahoney, A. (2010). Religion in families, 1999-2009: A relational spirituality framework. Journal of Marriage and Family, 72, 805-827. https://doi.org/10.1111/j.1741-3737.2010.00732.x

Mookherjee, H. N. (1997). Marital status, gender and perceptiton of well-being. The Journal of Social Psychology, 137(1), 95-105. https://doi.org/10.1080/00224549709595417

Morris, W. (2001). The American heritage dictionary of the English language (4th ed.). New York: Houghton Mifflin.

Myers, J. E., Sweeney, T. J., \&Witmer, J. M. (2000). The Wheel of wellness counseling for wellness: A holistic model for treatment plannig. Journal of Counseling and Development, 78(3), 251266. https://doi.org/10.1002/j.1556-6676.2000.tb01906.x

Ng, K. M., Loy, J. T. C., Gudmunson, C. G., \& Cheong, W. (2009). Gender differences in marital and life satisfaction among Chinese Malaysians. Sex Roles, 60(1-2), 33-43.

Orbuch, T. L., House, J. S., Mero, R. P., \& Webster, P. S. (1996). Marital quality over the life course. Social Psychology Quarterly, 162-171. https://doi.org/10.2307/2787050

Özbey, S. (2012). Ebeveynlerin evlilik uyumu ve algıladıkları sosyal destek ile altı yaş çocuklarının problem davranışları arasındaki ilişkinin incelenmesi. Kastamonu Eğitim Dergisi, 20(1), 43-62.

Özgüven, İ.E. (2000). Evlilik ve aile terapisi. Ankara: Pdrem Yayınları.

Perrone-McGovern, K. M., Boo, J. N., \&Vannatter, A. (2012). Marital and life satisfaction among gifted adults. Roeper Review, 34(1), 46-52. https://doi.org/10.1080/02783193.2012.627552

Robinson, L. C., \& Blanton, P. W. (1993). Marital strengths in enduring marriages. Family Relations, 42, 38-45. https://doi.org/10.2307/584919

Rosen-Grandon, J. R., Myers, J. E., \& Hattie, J. A. (2004). The relationship between marital characteristics, marital interaction processes and marital satisfaction. Journal of Counseling and Development, 82, 58-68. https://doi.org/10.1002/j.1556-6678.2004.tb00286.x

Roth, P. (1988). Spiritual well-being and marital adjustment. Journal of Psychology and Theology, 16, 153-158. https://doi.org/doi.org/10.1177/009164718801600204 
Ryan, R. M., \& Deci, E. L. (2001). To be happy or to be self-fulfilled: A review of research on hedonic and eudaimonic well-being. In S. Fiske (Ed.), Annual Review of Psychology (pp.141166). Palo Alto, CA: Annual Reviews, Inc.

Salarifer, M. R., Musaviasl, S. M., Şücai, M. S. \& Devlethah, M. (2014). İslami kaynaklar ışı̆̆ında ruhsal hijyen (K. Çamurcu, Çev.) İstanbul: El Mustafa Yayınları.

Sawatzky, R., Ratner, P. A., \& Chiu, L. (2005). A Meta analysis of the relationship between spirituality and quality of life. Social Indicators Research, 72(2), 153-188.

Schumm, W. R. (1985). Beyond relationship characteristics of strong families: Contrasting a model of family strengths. Family Perspective, 19, 1-9.

Seligman, M. E. P. (2007). Gerçek mutluluk (S. Kunt, Çev.) Ankara: HYB Yayınları.

Soylu, Y., \& Kağnıc1, D. Y. (2015). Evlilik uyumunun empatik eğilim, iletişim ve çatışma çözme stillerine göre yordanmas1. Türk Psikolojik Danışma ve Rehberlik Dergisi, 5(43), 44-54.

Spanier, G. B., \& Lewis, R. A. (1980). Marital quality: A review of the seventies. Journal of Marriage and the Family, 42(4), 825-839. https://doi.org/10.2307/351827

Stone, E., \& Shackelford, T. (2007). Marital satisfaction. In R. F. Baumeister \& K. D. Vohs (Eds.). Encyclopedia of social psychology (pp. 541- 544).Thousand Oaks, CA: Sage.

Strycharz, S. J. (2004). The relationship of spirituality and marital satisfaction among Roman Catholic couples. Dissertation Abstracts International: Section B: The Sciences and Engineering, 64, 4115.

Stutzer, A., \& Frey, B. S. (2006). Does marriage make people happy, or do happy people get married? The Journal of Socio-Economics, 35(2), 326-347.

Sullivan, K. T. (2001). Understanding the relationship between religiosity and marriage: An investigation of the immediate and longitudinal effects of religiosity on newlywed couples. Journal of Family Psychology, 15(4), 610-626. https://doi.org/10.1037/0893-3200.15.4.610

Tezer, E. (1986). Evli eşler arasındaki çatışma davranışları: Algllama ve doyum (Doktora tezi, Hacettepe Üniversitesi, Ankara). Retrieved from https://tez.yok.gov.tr/UlusalTezMerkezi/

Turner, R. P., Lukoff, D., Barnhouse, R. T., \& Lu, F. G. (1995). Religious or spiritual problem:A culturally sensitive diagnostic category in the DSM-IV. The Journal of nervous and mental disease, 183(7), 435-444.

Tutarel-Kışlak, Ş. \& Göztepe, I. (2012). Duygu dışavurumu, empati, depresyon ve evlilik uyumu arasındaki ilişkiler. Ankara Üniversitesi Sosyal Bilimler Enstitüsü Dergisi, 3(2), 27-46.

Tülek, N. (2011). Evli bireylerin öznel iyi olma düzeylerinin yordanması (Yayımlanmamış Yüksek Lisans Tezi, Ege Üniversitesi, İzmir). Retrieved from https://tez.yok.gov.tr/UlusalTezMerkezi/

Ümmet, D. (2017). Genel psikolojik sağlık ile yaşam doyumu arasındaki ilişkide evlilik uyumunun aracı rolü. İnsan ve Toplum Bilimleri Araştırmaları Dergisi, 6(1), 159-175.

Van Dierendonck, D., \& Mohan, K. (2006). Some thoughts on spirituality and eudaimonic well-being. Mental Health, Religion \& Culture, 9(3), 227-238. https://doi.org/10.1080/13694670600615383

Wills, E. (2009). Spirituality and subjective well-being: Evidences for a new domain in the personal well-being index. Journal of Happiness Studies, 10(1), 49-69.

Wilson, W. (1967). Correlates of avowed happiness. Psychological Bulletin, 67, 294-306. http:// dx.doi.org/10.1037/h0024431

Wolfinger, N. H., \& Wilcox, W. B. (2008). Happily ever after? Religion, marital status, gender and relationship quality in urban families. Social Forces, 86(3), 1311-1337. https://doi.org/10.1353/ sof.0.0023 
Yazıcı Çelebi, G. (2016).Bağlanma stilleri, ilişkilere ilişkin bilişsel çarpıtmalar, kişilerarası iliş̧i tarzları ve kişilik özelliklerinin evlilik uyumunu yordamadaki rolünün incelenmesi (Doktora tezi, Karadeniz Teknik Üniversitesi Eğitim Bilimleri Enstitüsü, Trabzon). Retrieved from https://tez. yok.gov.tr/UlusalTezMerkezi/

Yıldız, M. A., \& Baytemir, K. (2016). Evli bireylerde evlilik doyumu ile yaşam doyumu arasındaki ilişkide benlik saygısının aracılığı. İnönü Üniversitesi Eğitim Fakültesi Dergisi, 17(1), 67-80. http://dx.doi.org/10.17679/iuefd.17181627

Yıldız, M. A., \& Büyükşahin-Çevik, G. (2016). Evli bireylerin evlilik doyumlarının ve yaşam doyumlarının incelenmesi. Uluslararası Insan Bilimleri Dergisi, 13(1), 227-242. https://doi. org/10.14687/ijhs.v13i1.3417

Zullig, K. J., Ward, R. M., \& Horn, T. (2006). The association between perceived spirituality, religiosity, and life satisfaction: The mediating role of self-rated health. Social Indicators Research, 79(2), 255.

https://www.cnnturk.com/turkiye/turkiyede-son-10-yilda-evlilikler-azaldi-bosanmalar-artti Retrieved in 30.05 .18 